\title{
Pelaksanaan Pembelajaran Pendidikan Agama Islam pada Anak Autis di Sekolah SLB Restu Ibu Bukittinggi
}

\author{
Almuhardi Safarman*, Junaidi \\ Pendidikan Agama Islam, Institut Agama Islam Negeri (IAIN) Bukittinggi, Indonesia \\ *almuhardisafarman82@gmail.com
}

\begin{abstract}
Abstrak
Latar belakang penelitian ini adalah sebagian anak autis sulit untuk berkomunikasi interaktif dengan orang lain. Kadang, jawaban mereka tidak selalu sesuai dengan hal yang ditanyakan. Bahkan ada anak yang sulit untuk bergaul dengan teman-temannya karena sifatnya yang lebih suka menyendiri. Berdasarkan masalah tersebut, maka tujuan penelitian ini adalah mengidentifikasi bagaimana pihak sekolah melaksanakan pembelajaran pada anak autis berdasarkan kekurangan anak tersebut. Penelitian lapangan (field research) ini dilaksanakan di SLB Restu Ibu Bukittinggi. Informan dalam penelitian ini adalah guru pendidikan agama islam (PAI) dan kepala sekolah. Teknik pengumpulan datanya adalah dengan observasi, wawancara, dan dokumentasi. Beberapa usaha-usaha yang dilakukan pihak sekolah dalam pelaksaan pembelajaran PAI adalah dengan cara melakukan praktek secara langsung, atau memberi teguran secara langsung. Misalnya seperti latihah sholat dan dzikir. Tetapi di sekolah tidak memberikan latihan puasa kepada anak autis, serta tidak juga melakukan pendekatan visual dikarenakan sekolah lebih mengutamakan untuk berinteraksi secara langsung antara pendidik dan peserta didik. Akibatnya, tidak semua anak menjadi aktif karena masih ada anak yang belum mengalami perubahan.
\end{abstract}

Kata kunci: anak autis, pendidikan agama islam, sekolah luar biasa.

Dikirim: 26 November $2021 \quad$ Direvisi: 15 Desember 2021

Diterima: 23 Desember 2021

Identitas Artikel:

Safarman, A., Junaidi, J. (2022). Pelaksanaan Pembelajaran Pendidikan Agama Islam pada Anak Autis di Sekolah SLB Restu Ibu Bukittinggi. Jurnal Ilmu Pendidikan (JIP) STKIP Kusuma Negara, 13(2), 174-186.

\section{PENDAHULUAN}

Pendidikan adalah usaha sadar dan terencana untuk mewujudkan susana belajar dan proses pembelajaran (Junaedi, 2019), agar peserta didik secara aktif mengembangkan potensi dirinya untuk memiliki kekuatan spiritual, keagamaan, pengendalian diri, kepribadian, kecerdasan, akhlak mulia, serta keterampilan yang diperlukan dirinya, masyarakat, bangsa, dan negara (Kholis, 2014; Raharjo, 2010; Kurniawan, 2015). Pendidikan sendiri terbagi menjadi tiga macam yaitu: (1) pendidikan formal yaitu jalur pendidikan yang terstruktur dan berjenjang yang terdiri atas pendidikan dasar, pendidikan menengah, dan pendidikan tinggi, (2) pendidikan nonformal yaitu jalur pendidikan di luar pendidikan formal yang dilaksanakan secara terstruktur dan berjenjang, (3) pendidikan informal yaitu jalur pendidikan keluarga dan lingkungan (Bafadhol, 2017; Hasanah, 2019; Darlis, 2017). Sebagaimana dalam firman Allah SWT dalam QS. An-Nisa ayat 9, "Dan hendaklah takut kepada Allah orang-orang yang seandainya meninggalkan di belakang mereka anak-anak yang lemah, yang mereka khawatir terhadap 
(kesejahteraan) mereka. Oleh sebab itu hendaklah mereka bertakwa kepada Allah dan hendaklah mereka mengucapkan perkataan yang benar."

Isi yang telah disebutkan dalam Undang-undang Republik Indonesia No. 20 Tahun 2003 tentang sistem Pendidikan Nasional menjelaskan dalam pasal 5 ayat 2 juga menunjukan bahwa anak autis mendapatkan hak yang sama untuk pendidikan. Sedangkan pendapat lain mengatakan bahwa pendidikan adalah segala usaha orang dewasa dalam pergaulannya dengan anak-anak untuk memimpin perkembangan jasmani dan rohaninya kearah kedewasaan (Karimah, 2018; Suparlan, 2020; Inda, Anggraini, \& Ginting, 2021). Pendidikan juga merupakan pimpinan yang diberikan dengan sengaja oleh orang dewasa kepada anak-anak, dalam pertumbuhannya (jasmani dan rohani) agar berguna bagi diri sendiri dan bagi masyarakat (Umar, 2019). Sementara itu PAI adalah pendidikan yang dalam pelaksanaannya berdasarkan pada ajaran islam (Taubah, 2015). Karena ajaran islam berdasarkan Al-Quran, Al-Sunnah, pendapat ulama, serta warisan sejarah maka PAI juga mendasarkan diri pada Al-Quran, Al-Sunnah, pendapat ulama dan warisan sejarah tersebut (Nata, 2016).

Sedangkan autisme adalah suatu masalah yang ganjil diawal masa kanakkanak (Zulkafli, Majid, \& Ishak, 2018), dimana anak gagal mengembangkan hubungan yang normal kepada kedua orang tuanya (Yatim, 2002; Pamuji, 2014). Anak menunjukkan sikap yang tidak bersahabat dan sering lambat bicara. Anak yang mengidap autisme diyakini bahwa separuhnya kerusakan otak dan lebih dari setengahnya menderita keterbelakangan mental yang parah. Mereka mengalami kesulitan untuk berhubungan dengan orang lain. Jika seorang bayi mengidap penyakit autisme maka bayi tidak mau merapatkan ke tubuh ibuhnya sewaktu digendong atau dipeluk, bayi juga lebih sering meronta dan merenggangkan badannya. Setelah anak bertambah besar maka kesanggupan daya khayalnya kurang, karena itu ia sering menulang-ulang kalimat yang sama dan terus menerus (Dachlan, Erfansyah, \& Taseman, 2019)

Ganguan autisme membutuhkan kehadiran tiga gejala yaitu: gangguan interaksi sosial, kurangnya kemampuan komunikatif, dan ada perilaku stereotip (Carlson, 2012; Rahmahtrisilvia, Setiawan, Fatmawati, \& Sopandi, 2021). Sampai saat ini tidak ada pengobatan atau perawatan medis bagi anak penderita autisme, tapi pengaturan dan pendidikan yang cocok akan sangat menolong dan akan memunculkan kesanggupan tersembunyi apapun yang ada pada anak. Seluruh masa depan anak sangat tergantung pada kemampuannya untuk berkomunikasi dengan orang lain untuk berbicara dan mengembangkan perhatian sosial serta memperoleh dan mengembangkan keterampilan teknis (Dachlan, dkk., 2019).

Sebagian dari anak autis kadang sulit untuk berkomunikasi interaktif dengan orang lain. Kadang, jawabannya tidak selalu sesuai dengan hal yang ditanyakan. Bahkan ada anak yang sulit bergaul dengan teman-temannya karena sifatnya yang lebih suka menyendiri. Berdasarkan masalah tersebut, maka penelitian ini bertujuan untuk mengidentifikasi bagaimana pihak sekolah dalam melaksanakan pembelajaran PAI pada anak autis sesuai dengan kebutuhan anak tersebut.

\section{METODE PENELITIAN}

Jenis penelitian yang penulis gunakan dalam penelitian ini adalah penelitian lapangan (field research). Sedangkan metode penelitian yang penulis gunakan 
adalah deskriptif kualitatif yaitu "prosedur penelitian yang mengahsilkan data deskriptif berupa kata-kata tertulis atau lisan dari orang-orang dan perilaku yang dapat diamati (Lubis, 2018). Penelitian ini dilakukan di sekolah SLB Restu Ibu Bukittinggi. Informannya ada dua orang yaitu: guru PAI sebagai informan kunci dan kepala sekolah sebagai informan pendukung.

Dalam penelitian ini, ada tiga cara dalam teknik mengumpulkan data. Pertama adalah observasi. Teknik kedua adalah wawancara. Wawancara yang dilakukan adalah seputar bagaimana cara guru PAI dalam menyampaikan pembelajaran PAI kepada anak autis. Teknik ketiga adalah dokumentasi, yaitu berupa dokumen yang berkaitan dengan penelitian. Setelah data diperoleh, data yang diperoleh dari hasil observasi, wawancara, dan dokumentasi dikelompokan dan disusun secara sistematis. Kemudian, analisis dilakukan terhadap data tersebut. Teknik Analisis datanya adalah analisis deskriptif kualitatif. Data yang diperoleh melalui observasi, wawancara dan dokumentasi kemudian akan disusun kedalam sebuah penelitian. Proses ini dilakukan dengan cara menyeleksi atau menyunting data tersebut, mana yang harus dibuang, selanjutnya diidentifikasi atau dikelompokan sesuai variabel, dan disajikan dalam bentuk hasil penelitian.

\section{HASIL DAN PEMBAHASAN}

Sekolah SLB Restu ibu adalah salah satu sekolah yang memberikan pendidikan terhadap anak berkebutuhan khusus, dan salah satu anak yang berkebutuhan khusus itu adalah anak autis. Sedangkan anak autis ini adalah anak yang memiliki gangguan perkembangan kognitif serta kekurangan dari segi mental, berkomunikasi, berinteraksi dengan orang lain. Sekolah SLB Restu Ibu Bukittinggi ini mengadakan pembelajaran PAI untuk anak autis. Berikut beberapa hasil penelitian.

\section{Penanaman Akhlak yang baik}

Penanaman akhlak yang baik pada anak autis dapat dilakukan dengan kelembutan dan kasih sayang, serta jika anak tersebut berakhlak yang tidak baik maka guru bisa menegur anak autis tersebut secara langsung dengan penuh kasih sayang dan kelembutan. Hal ini sesuai sesuai penjelasan dari informan kunci sebagai berikut.

"Anak autis membutuhkan kasih sayang dan kelembutan sehingga ketika guruguru di sekolah ini melihat ada anak yang berakhlak kurang baik maka metode yang digunakan untuk menanamkan akhlak yang baik adalah dengan menegurnya secara langsung, tetapi tidak dengan kekerasan dan harus dengan kelembutan serta kasih sayang. Jika anak autis ditegur secara keras maka dia akan menjadi takut kepada kita."

Penanaman akhlak yang baik itu akan dilakukan secara berulang-ulang sampai anak tersebut terbiasa dengan perbuatan baik itu. Hal ini seperti penjelasan dari informan pendukung sebagai berikut.

"Mendidik anak autis itu membutuhkan kesabaran dan dilakukan dengan berulang-ulang sampai anak tersebut terbiasa melakukannya. Kami tidak berhenti melakukannya tatkala anak masih berbuat hal yang sama, dan kami 
mendidik anak tersebut dengan berulang-ulang dikarenakan anak ini memiliki beberapa kebutuhan khusus yang terkadang mereka juga kesulitan menangkap kata-kata. Mereka tidak sama seperti anak-anak normal pada umumnya, sehingga metode yang bisa digunakan untuk menanamkan akhlak yang baik adalah dengan cara menegurnya berulang-ulang disertai penuh kesabaran dan kasih sayang".

Sebagai mana dijelaskan dalam teori, karena anak autis ini menunjukkan defisit perilaku, fokus utama dari modifikasi perilaku adalah pengembangan perilaku baru (Alessandra \& R-Suradijono, 2020). Lebih lanjut, perilaku baru ini dipertahankan dengan adanya reinforce, sehingga penting untuk mengajarkan kepada anak-anak yang biasanya merespon orang lain seperti mereka berhadapan dengan benda mati. Untuk menerima orang lain sebagai reinforce, maka dilakukan dengan cara memasangkan pujian dengan reinforce primer seperti makanan (Bektiningsih, 2009). Selanjutnya reinforcer sosial (pujian) dan reinforcer makanan ini dapat digunakan untuk membentuk dan memberi contoh perilaku di kamar kecil, bicara, dan bermain sosial (Nurina, 2015). Berikut penjelasan dari informan pendukung terkait kondisi tersebut.

"Anak autis tersebut memiliki sifat cuek dan tidak mau tahu dengan orang lain, bahkan anak tersebut hanya kenal dengan guru wali kelasnya saja, mereka kadang tidak mau kenal dengan guru lain termasuk kepada saya. Cara mendidik mereka adalah melalui guru kelasnya yang selalu meminta mereka untuk bersalaman dengan guru-guru lain atau kepada siapa saja tamu yang datang ke sekolah ini."

Hasil wawancara tersebut didukung pula oleh hasil observasi. Menurut hasil pengamatan, ternyata anak autis pada awalnya memang belum ingin menyalami orang yang baru dikenalnya, tetapi setelah guru agama meminta mereka untuk bersalaman, maka mereka akan melakukannya. Dengan demikian, menanamkan akhlak yang baik pada anak autis dilakukan dengan kesabaran kasih sayang serta perhatian (Nunsiyah, 2019). Hal itu perlu dilakukan berulang-ulang dengan cara ditegur secara langsung karena mereka memiliki kebutuhan khusus dimana daya tangkapnya tidak selalu sama seperti anak normal pada umumnya.

\section{Berbicara dengan baik dan sopan}

Cara mendidik anak autis dalam berbicara yang baik dan sopan adalah dengan menegurnya secara langsung. Hal ini sesuai dengan penjelasan dari informan kunci sebagai berikut.

"Sebenarnya mendidik anak agar mereka berbicara dengan baik dan sopan adalah dengan menegurnya secar langsung. Misalnya di saat siswa bersuara keras kepada orang lain, maka guru akan menegurnya langsung dengan ucapan bahwa mereka tidak harus berbicara seperti itu, dengan alasan karena nanti Allah akan marah kepada kita. Bahkan ada anak di sini yang awal masuk belum mampu memahami perkataan orang lain, dan dalam jangka tiga tahun guru bisa membimbingnya untuk berbicara dan merespon ucapan orang lain." 
Data hasil pengamatan juga menunjukan bahwa ketika ada guru memanggil seorang anak, katakan namanya Zahra, dan tidak lama kemudian anak tersebut datang menghampiri. Berdasarkan kondisi tersebut, informan kunci menjelaskan hal berikut.

"Itulah anak yang pada awalnya belum bisa berkomunikasi dengan orang lain, tetapi hari ini dia sudah bisa merespon ucapan orang lain dengan baik. Kami dulu membimbingnya cukup sulit, penuh kasih sayang, perhatian, dan jika dia sedang jajan maka kami biasanya bertanya kepada dia "zahra lagi makan apa?" Kami selalu memberikan perhatian yang penuh pada anak autis dengan sering menyapanya sampai mereka terbiasa menggunakan ucapan yang sering diucapkan itu."

Selanjutnya, di saat ada anak yang kurang sopan dalam berbicara, contohnya memekik atau bersuara keras, maka guru menasehatinya terus menerus secara bertahap. Hal ini sesuai pendapat dari informan pendukung berikut.

"Anak autis memiliki sifat pelupa, maka mereka tidak perlu disalahkan jika mereka berbuat kesalahan berulang-ulang di kemudian hari. Contohya memekik, bersuara keras ketika belajar, maka mereka perlu diingatkan terus menerus. Kadang, anak autis juga suka mengulang-ulang pertanyaan yang guru tanyakan, maka guru biasanya bertanya kepada anak tersebut sambil mengusap kepalanya. Ada anak autis yang suka memekik keras-keras, maka guru menasehatinya dengan lembut dan berulang karena suatu saat dia bisa berbuat hal yang sama di lain kesempatan. Guru juga tidak merasa bosan untuk menasehatinya sampai mereka terbiasa berkata yang baik".

Berdasarkan wawancara di atas, dan dikuatkan lagi dengan hasil observasi, ketika salah seorang anak bertanya nama observer, dengan kalimat "om nama om siapa?" Observer menjawab, katakan namanya adalah Al. Pada saat observer bertanya balik kepada anak autis tersebut, jawaban anak itu adalah "namanya Om Al". Akibatnya, salah satu guru menegurnya secara langsung dengan pertanyaan yang sama berulang-ulang, dan anak itu kemudian menyebutkan nama dirinya. Di sini, dapat disimpulkan bahwa mendidik anak autis dalam berbicara yang baik dan sopan dapat dilakukan juga secara berulang atau ditegur secara langsung dengan lembut dan tidak disertai dengan amarah atau kekerasan. Hal itu dilakukan sampai anak terbiasa berkata yang baik dan sopan (Asna, 2018).

\section{Membaca Al-Quran}

Anak autis juga diajarkan pendidikan membaca Al-Quran mulai dari pengenalan huruf-huruf hijaiyah sampai mereka mampu membacanya. Mereka juga membutuhkan hal itu seperti anak pada umumnya. Informan kunci menyatakan sebagai berikut.

"Dalam mengajarkan bacaan Al-Quran kepada anak anak autis, metode yang digunakan adalah talqin dan berhadapan langsung dengan siswa tersebut. Guru mengajarkan tentang pengenalan pengenalan huruf hijaiyah agar 
mereka bisa membedakan huruf. Kemudian guru menngajarkan membaca Iqra' sampai dengan membaca Al-Quran. Anak di sini juga ada yang bisa membaca Al-Quran. Sekolah ini menyediakan semua perlengkapan anak berkebutuhan khusus supaya mereka tidak perlu membawanya dari rumah."

Anak autis juga kebanggaan orang tua maka mereka harus mendapatkan pendidikan seperti anak yang lain. Meskipun dalam pelaksanaannya bahwa kecepatan pemahaman mereka tidak sama seperti anak yang bukan berkebutuhan khusus. Guru juga tentu akan merasa bangga tatkala anak-anak ini bisa membaca Al-Quran dengan baik dan benar. Bentuk dukungan yang diberikan kepada anak autis dalam membaca Al-Quran adalah dengan memberikannya hadiah dan pujian ketika mereka sudah mampu membaca ayat-ayat pendek. Hal ini sesuai penjelasan dari informan pendukung.

"Kami biasanya mengadakan beberapa acara pada hari jumat pagi termasuk dalam membaca ayat-ayat pendek, membaca Al-Quran. Guru meminta anak membacanya. Ketika anak mampu membaca ayat-ayat pendek tersebut maka guru akan memberikan mereka hadiah dan pujian sehingga mereka tetap bersemangat. Sampai hari ini bahwa anak-anak tetap bersemangat membaca Al-Quran, meskipun belum semuanya mampu".

Di sisi lain, Al-Quran dianggap sebagai terapi yang pertama dan utama, sebab didalamnya memuat resep-resep mujarab yang dapat menyembuhkan penyakit jiwa manusia (Mufidah, 2015). Lebih lanjut, tingkat kemujarababnnya sangat tergantung seberapa jauh tingkat sugesti keimanan seseorang (Muzakkir, 2019). Mengajarkan anak membaca Al-Quran menjadi penting meskipun anak memiliki sedikit keterbatasan. Anak autis juga harusnya mendapat pendidikan seperti anak normal pada umumnya, walaupun mengajarkan mereka membaca Al-Quran tidak sama seperti anak pada umumnya. Mengajarkan anak autis membutuhkan waktu yang sedikit lebih lama dari anak pada biasanya. Jadi guru akan mengajarkan secara bertahap di samping memberikan bentuk support kepada mereka apakah itu hadiah atau pujian supaya tetap bersemangat dalam membaca Al-Quran.

\section{Sholat}

Sholat juga diajarkan pada anak autis setiap hari secara bersama-sama dengan anak berkebutuhan khusus lainnya. Kegiatan ini untuk melatih kemandirian anak tersebut. Hal ini sesuai dengan penjelasan informan kunci sebagai berikut.

"Metode yang kami terapkan untuk adalah dengan metode demonstarsi. Ketika sholat berjamaah, maka seorang anak yang tidak tergolong autis akan menjadi imam dan anak yang lainnya mengikuti gerakannya dari dibelakang. Ketika ada anak autis tidak mengikutinya, maka guru akan membimbingnya untuk gerakan seperti ruku', sujud, dan lain-lain. Guru mengajarkan anak autis untuk sholat berjamaah setiap hari bersama anak berkebutuhan khusus lainnya agar terbiasa dan terlatih kemandiriannya. Seandainya anak itu tidak diajarkan melaksanakan sholat, bisa jadi mereka tidak melaksanakannya sampai dewasa nanti”. 
Kemudian untuk menguatkan pendapat di atas, berikut adalah penjelasan dari informan pendukung.

"Untuk melaksanakan sholat ini guru tidak hanya mengajarkan anak tentang sholat saja, tetapi juga mengajarkan mereka mulai dari bagaimana tata cara berwudhu dengan baik dan benar. Jika anak sudak bisa berwudhu secara benar maka mereka baru akan diajarkan tentang sholat."

Di sisi lain, ternyata salah satu diantara anak autis itu ada yang non muslim. Hal ini seperti penjelasan dari informan kunci.

"Anak autis di sekolah ini ada 10 orang, dan diantaranya ada satu orang yang non muslim. Di saat guru melaksanakan kegiatan keagamaan bersama anakanak lain, seperti sholat atau mengaji, maka anak yang non muslim tersebut tidak datang ke sekolah."

Selanjutnya, pada saat sholat zuhur, anak-anak diminta untuk berwudhu. Beberapa anak dibantu guru mencucikan tangan dan wajah mereka, dan semua guru di sekolah mengatur mereka untuk melaksanakan sholat. Wulur (2015) menyatakan bahwa sholat adalah perpaduan aktivitas fisik dan psikis. Ketika tubuh bergerak maka otak memegang kendali ingatan seseorang tertuju pada bacaan dan jenis gerakan. Dalam waktu yang bersamaan, hati mengikuti dan membenarkan tindakan. Gerakan sholat merupakan gerakan paling sempurna untuk menjaga kondisi kesehatan tubuh kita (Muzakkir, 2019).

Dari penjelasan dua orang informan, bahwa mengajarkan sholat kepada anak sejak usia dini merupakan suatu kewajiban bagi orang tua. Sebaiknya orang tua tetap mengajarkan sholat kepada anak walaupun mereka memiliki kebutuhan khusus seperti autis, karena di setiap gerakan sholat memiliki makna kesehatan tertentu (Cahyono, 2019). Sholat juga dijadikan terapi untuk anak autis sehingga perlu diajarkan kepada kepada anak setiap hari meskipun mereka belum berkewajiban melaksanakannya tetapi setidaknya gerakan sholat bisa dijadikan sebagai terapi (Muhtar, 2016).

\section{Dzikir}

Dzikir juga penting untuk diajarkan kepada anak autis. Melalui berdzikir, anakanak autis, mereka yang hyper, bisa menjadi lebih tenang dengan kalimat dzikir itu. Hal ini sesuai penjelasan dari informan kunci sebagai berikut.

"Kami juga mengajarkan beberapa kalimat zikir dan sholawat pada anak autis. Dzikir itu menenangkan sehingga merupakan suatu hal positif untuk mereka. Alhamdulillah sampai saat ini anak cukup antusias mempraktekan dzikir. Guru mengajarkan kalimat dzikir seperti kalimat takbir, tasbih, tahmid, dan tahlil. Metode yang guru gunakan adalah talqin. Guru membacakan kalimat-kalimat dzikir kemudian semua anak autis mengulanginya".

Penjelasan tersebut dikuatkan oleh pendapat dari informan pendukung sebagai berikut. 
"Kalimat zikir-dzikir itu diajarkan setelah anak melaksanakan sholat berjamaah. Guru meminta anak untuk membaca dzikir secara bersama-sama dengan anak berkebutuhan lainnya. Jika anak tidak diajarkan secara bersama-sama maka ada potensi kesulitan mengajarkan anak autis, tapi jika bersamaan dengan anak lainnya maka anak autis akna dengan sendidirinya bisa mengikuti bacaan dzikir teman-temannya yang lain. Sejauh ini sudah banyak perkembangan yang ditunjukan meskipun guru tidak mengajarkan kalimat dzikir yang panjang, tetapi setidaknya guru sudah mengajarkan kalimat dzikir sesuai dengan kesanggupan anak."

Berdasarkan wawancara dan observasi, saat anak-anak selesai melaksanakan sholat maka guru-guru dengan bersamaan juga membaca kalimat-kalimat dzikir di ikuti oleh semua anak-anak di sekolah. Dengan demikian, dapat dipahami bahwa kalimat dzikir berpengaruh penting dalam kehidupan karena bisa menenangkan dan dapat melatih kamandirian anak. Pelajaran yang bisa diambil adalah jika anak yang berkebutuhan khusus, seperti anak autis, dilatih berdzikir, maka itu juga harus dilakukan oleh mereka yang tidak berkebutuhan khusus seperti anak-anak tersebut (Rahmawati, Firdaus, \& Selamet, 2020). Sudah menjadi kewajiban bagi kita untuk melatih anak untuk berdzikir.

As-Sakandari (2018) menyatakan bahwa sebagaimana manfaat dari dzikir adalah mengusir, menghadang, bahkan menghancurkan setan. Lebih lanjut, dzikir membuat senang Ar-Rahman, membuat marah setan, menghilangkan kesusahan dan kesedihan, mendatangkan kegembiraan dan kebahagiaan, menghilangkan duka dan keburukan. Dzikir dapat menguatkan hati dan tubuh, memperbaiki batin dan zohir, membuat hati dan wajah berseri cerah, serta mendatangkan dan memudahkan rizki. Dzikir dapat pula mendatangkan wibawa bagi pedzikir, mengilhami untuknya mengetahui sisi yang benar dalam segala hal, dan mengerjakannya dengan lenggeng.

\section{Puasa}

Anak autis di sekolah ini tidak dilatih untuk melaksanakan puasa. Anak suka jajan dan membawa makanan dari rumah. Hal ini sesuai pendapat informan kunci sebagai berikut.

"Guru di sini belum melatih anak autis berpuasa karena salah satu kebiasaan anak autis adalah suka jajan. Bahkan anak tidak hanya jajan di sekolah, tapi juga mereka membawa banyak makanan ke sekolah. Sambil belajar juga mereka biasanya makan, atau kadang mereka ada yang sedang belajar tibatiba langsung keluar untuk jajan."

Untuk memperkuat pendapat tersebut, hasil observasi pada sepuluh anak autis menemukan mereka sedang memakan makanan ringan sambil mengikuti pembelajaran. Selanjutnya, informan kunci memberi penjelasan berikut.

"Jika anak autis dibantah untuk jajan maka mereka akan merasa badmood dan bisa marah dengan guru. Guru biasanya membiarkan mereka makan asalkan tetap mau dan sambil belajar. Guru mengatakan kepadanya anak bahwa "jika sudah jajan selanjutnya belajar ya". Dengan demikian anak akan 
belajar. Di sisi lain, ada anak autis yang non muslim yang tentu saja tidak diwajibkan untuk melaksanakan puasa."

Berdasarkan wawancara dan observasi, anak autis bisa melaksanakan pembelajaran sambil memakan makanan ringan. Kadang anak meminta bantua kepada guru untuk membukakan makanannya. Anak autis di sekolah tersebut belum dilatih melaksanakan puasa karena mereka masih suka jajan. Sanjaya (2020) mengemukakan bahwa puasa itu memiliki banyak keutamaan bahkan orang sakit jiwa sekalipun bisa sembuh dengan terapi puasa. Anak autis akan merasakan manfaatnya jika mereka dilatih berpuasa. Tetapi penjelasan dari para informan bahwa anak masih dibiarkan jajan asalkan anak mau belajar di samping mereka juga diajarkan melaksanakan puasa meskipun belum diwajibkan baginya.

Sedangkan puasa memberikan pengaruh yang baik yaitu Allah akan memberikan berkah kepada orang yang berpuasa. Seperti ditegaskan oleh sabda Nabi Muhammad SAW yang diriwayatkan oleh Ibnu Suny dan Abu Nu'aim bahwa "berpuasalah maka kamu akan sehat". Kinanthi (2017) menyatakan bahwa hebatnya manfaat puasa bahwa di Amerika Serikat ada puasa yang diberi nama "Fasting Center International Inc.", yaitu suatu lembaga yang menangani masalah puasa, program penurunan berat badan, program mengeluarkan toksin tubuh, program memperbaiki energi, kesehatan mental, kesehatan fisik dan yang paling terpenting meningkatkan kualitas hidup. Sejak zaman dahulu puasa juga dipakai untuk mengobati sakit fisik maupun mental. Paracelsus (dalam Kinanthi, 2017) menyatakan bahwa "fasting is the greatest remedy the physician within".

\section{Pendekatan Visual}

Pendekatan visual juga jarang dilaksanakan di sekolah karena guru lebih memilih metode tanya jawab dan interaksi langsung antara guru dan murid. Hal ini sesuai pendapat dari informan kunci sebagai berikut.

"Guru di sini jarang menggunakan pendekatan visual dalam pembelajaran agama karena lebih sering melakukan tanya jawab langsung dan berinteraksi dengan siswa. Pada awal-awal anak masuk ke sekolah ini, guru menggunakan pendekatan visual karena anak belum memiliki kedekatatan emosional dengan para guru. Tetapi setelah mereka merasa dekat dengan guru, maka pendekatan visual cenderung jarang dilaksanakan. Ketika guru mengadakan interaksi langsung dengan anak dengan cara tanya jawab langsung maka anak terbisa dengan interaksi tersebut."

Pendapat tersebut kemudian dikuatkan oleh pernyataan informan pendukung sebagai berikut.

"Diantara anak-anak autis itu, katakan sifatnya hipo, anak ini adalah anak yang sangat pendiam, jarang mau diajak berbicara, makan masih di suapin, mencuci tangannya masih dicucikan. Dia tidak sama dengan anak lainnya. Guru cukup sulit mengatasi kemauan atau kebiasaan anak ini. Tetapi guru menggunakan pendekatan visul kepada mereka, meskipun pada akhirnya banyak ketertinggalan dibanding anak-anak lain". 
Dari penjelasan dua orang informan tersebut, maka dapat dipahami bahwa pendakatan visual cenderung jarang dilaksanakan karena guru lebih suka berinteraksi dan komunikasi secara langsung kepada siswa. Akibatnya, anak yang memiliki sifat hipo akan cenderung tertinggal dibanding teman-temanya.

Selanjutnya, hasil observasi di sekolah tidak menemukan keberadaan media visual gambar yang sifatnya keagamaan, seperti gambar orang yang sedang berwudhu, sholat, atau lainnya. Informan kunci memberi penjelasan berikut.

"Kalau anak berwudhu maka guru ada yang mencucikan muka dan tangan anak. Kemudian meminta anak mencuci tangannya sendiri. Hal ini dilakukan sampai anak terbiasa sendiri tanpa harus guru bimbing kembali. Di sisi lain, masih ada beberapa orang anak hipo yang belum bisa melakukannya sendiri."

Lebih lanjut, informan pendukung menambahkan penjelasan terkait penggunaan media visual sebagai berikut.

"Saya mengajar pendidikan agama secara langsung dan tidak menggunakan media gambar atau media visual lainnya."

Berdasarkan wawancara dan observasi, maka dapat dipahami bahwa mendidik anak autis di sekolah lebih sering berinteraksi secara langsung, memberi teguran langsung, jarang menggunakan media gambar atau visual lainnya. Berinteraksi dan berkomunikasi langsung kepada anak autis dalah cara pengajaran yang lebih baik (Saihu, 2019).

\section{Motode Demonstrasi}

Metode demontrasi dilaksanakan setiap hari, bahkan dalam pembelajaran agama lebih sering digunakan oleh guru. Hal ini sesuai pendapat informan kunci sebagai berikut.

"Metode demontrasi sering digunakan guru, karena anak-anak bisa meniru langsung gerakan yang diperagakan gurunya. Seperti halnya membaca AlQuran dan berwudhu. Semuanya menggunakan metode demonstrasi."

Kemudian informan pendukung juga sejalan dengan pernyataan tersebut dengan menambahkan penjelasan berikut.

"Selain metode demonstrasi, guru juga menggunakan metode tanya jawab langsung dan interaksi langsung. Tanya jawab dan interaksi langsung akan menumbuhkan kedekatan antara guru dan anak-anak autis."

Hasil observasi juga mendokumentasikan bahwa ketika anak autis sholat, ada guru yang berdiri di depan sambil mengajarkan dan memperagakan kepada anakanak cara melipat tangan yang baik. Dari hasil penelitian, maka metode demonstrasi dan tanya jawab lansung lebih sering digunakan dalam pembelajaran PAI pada anak autis karena lebih mudah untuk dipahami oleh siswa autis. Dengan demikian, metode-metode yang lain cenderung jarang dilakukan, karena sejalan dengan Halimah, Pandikar, \& Azhari (2021) bahwa pembelajaran penting bagi 
anak autis adalah melalui pembiasaan. Jika sudah terbiasa berbuat sesutu maka akan mudah mendidik mereka.

\section{SIMPULAN}

Berdasarkan hasil penelitian, maka beberapa usaha sekolah dalam pelaksanaan pembelajaran PAI pada anak autis di sekolah SLB Restu Ibu Bukittinggi disimpulkan bahwa pembelajaran PAI yang dilakukan di sekolah tersebut lebih kepada praktek secara langsung seperti sholat, dzikir tetapi pihak sekolah tidak melaksanakan pendekatan visual karena sekolah tersebut lebih kepada interaksi langsung antara pendidik dan peserta didik.

\section{REFERENSI}

Alessandra, T. M., \& R-Suradijono, S. H. (2020). Modifikasi Perilaku untuk Meningkatkan Kepatuhan pada Anak dengan High Functioning Autism Spectrum Disorder. Seurune: Jurnal Psikologi Unsyiah, 3(1), 1-21. https://doi.org/10.24815/s-jpu.v3i1.15553

As-Sakandari, I. A. (2018). Seluk Beluk Dzikrullah. Pustaka Pesantren.

Asna, A. (2018). Pengasuhan keluarga islami dalam menangani anak autis. Dakwatuna: Jurnal Dakwah dan Komunikasi Islam, 4(1), 149-169. https://doi.org/10.36835/dakwatuna.v4i1.290

Bafadhol, I. (2017). Lembaga Pendidikan Islam di Indonesia. Edukasi Islami: Jurnal Pendidikan Islam, 6(11), 59-72. http://dx.doi.org/10.30868/ei.v6i11.95

Bektiningsih, K. (2009). Program terapi anak autis di SLB negeri semarang. Jurnal Kependidikan: Penelitian Inovasi Pembelajaran, 39(2), 95110. https://doi.org/10.21831/jk.v39i2.96

Cahyono, G. (2019). Pembelajaran PAI bagi Anak Autis Berwawasan Teknologi $\begin{array}{lll}\text { Pendidikan. Edukasia Islamika, } & \text { 62-76. }\end{array}$ https://doi.org/10.28918/jei.v4i1.2260

Carlson, N. R. (2012). Fisiologi Perilaku. Erlangga.

Dachlan, A. M., Erfansyah, N. F., \& Taseman, T. (2019). Perkembangan Sosial Emosional Anak Usia Dini. CV Budi Utama.

Darlis, A. (2017). Hakikat Pendidikan Islam: Telaah Terhadap Hubungan Pendidikan Informal, Non Formal dan Formal. Jurnal Tarbiyah, 24(1), 84103. http://dx.doi.org/10.30829/tar.v24i1.131

Halimah, L., Pandikar, E., \& Azhari, N. (2021). Upaya Guru dan Orang Tua Dalam Membangun Karakter Mandiri Siswa Autis di Sekolah Luar Biasa Negeri A Kota Cimahi. Jurnal Hurriah: Jurnal Evaluasi Pendidikan dan Penelitian, 2(3), 41-63.

Hasanah, N. M. (2019). Penyelenggaraan Jalur Pendidikan Formal dan Nonformal (Studi Kasus di PAUD Terpadu Salsabila Al-Muthi'in Yogyakarta). Early Chilhood Islamic Education and Development, 1(2), 84-97. http://dx.doi.org/10.15642/jeced.v1i2.462

Inda, S., Anggraini, D., \& Ginting, D. (2021). Peran orang tua untuk meningkatkan motivasi belajar anak di Desa Sei Nangka. RAMBATE, 1(1), 8184. 
Junaedi, I. (2019). Proses Pembelajaran yang Efektif. Journal of Information System, Applied, Management, Accounting and Research, 3(2), 19-25.

Karimah, U. (2018). Pondok Pesantren dan Pendidikan: Relevansinya dalam Tujuan Pendidikan. MISYKAT: Jurnal Ilmu-ilmu Al-Quran, Hadist, Syari'ah dan Tarbiyah, 3(1), 137-154. http://dx.doi.org/10.33511/misykat.v3n1.137

Kholis, N. (2014). Paradigma Pendidikan Islam Dalam Undang-undang Sisdiknas 2003. Jurnal Kependidikan, 2(1), 71-85. https://doi.org/10.24090/jk.v2i1.542

Kinanthi, M. (2017). Dahsyatnya 7 Puasa Wajib, Sunnah \& Thibbun Nabawi. Ide Segar Media.

Kurniawan, M. I. (2015). Mendidik untuk membentuk karakter siswa sekolah dasar: studi analisis tugas guru dalam mendidik siswa berkarakter pribadi yang baik. Pedagogia: Jurnal Pendidikan, 4(2), 121-126. https://doi.org/10.21070/pedagogia.v4i2.14

Lubis, M. S. (2018). Metodologi Penelitian. CV Budi Utama.

Mufidah, L. I. (2015). Pentingnya Psikoterapi Agama dalam Kehidupan di Era Modern. Jurnal Lentera: Kajian Keagamaan, Keilmuan dan Teknologi, 1(2), 181-196.

Muhtar, M. Y. (2016). Aku ABK, Aku Bisa Shalat. Gramedia Pustaka Utama.

Muzakkir, M. (2019). Hidup sehat dan bahagia dalam perspektif Tasawuf. Prenadamedia Group.

Nata, H. A. (2016). Pendidikan dalam Perspektif Al-Qur'an. Prenada Media.

Nunsiyah, H. O. (2019). Peran Orang Tua Dalam Menanamkan Akhlak Pada Anak Tunagrahita (Studi di SKh Al-Khairiyah Citangkil Kota Cilegon). Al Kahfi: Jurnal Pendidikan Islam Anak Usia Dini, 1(2), 1-14.

Nurina, P. (2015). Pendidikan Agama Islam Bagi Siswa Autis Pada Sekolah Inklusif. YPM Press.

Pamuji, P. (2014). Adaptasi Media Pembelajaran Gambar Untuk Meningkatkan Aktivitas Belajar Anak Autis. Jurnal Ortopedagogia, 1(2), 117-127. http://dx.doi.org/10.17977/um031v1i22014p117-127

Raharjo, S. B. (2010). Pendidikan karakter sebagai upaya menciptakan akhlak mulia. Jurnal Pendidikan dan Kebudayaan, 16(3), 229-238.

Rahmahtrisilvia, R., Setiawan, R., Fatmawati, F., \& Sopandi, A. A. (2021). Asesmen Gaya Belajar Anak Gangguan Spektrum Autisme. UNP Press.

Suparlan, S. (2020). Pendidikan Anak dalam Persepektif Islam. PENSA, 2(3), 249-261. https://doi.org/10.36088/pensa.v2i3.949

Rahmawati, R., Firdaus, A. H., \& Selamet, S. (2020). Implementasi pembelajaran pendidikan agama islam pada anak autis di sekolah luar biasa negeri Ciamis. Tarbiyat al-Aulad: Jurnal Pendidikan Islam Anak Usia Dini, 3(2), 89114.

Saihu, S. (2019). Komunikasi Pendidik Terhadap Anak Berkebutuhan Khusus Di Sekolah Khusus Asy-Syifa Larangan. Andragogi: Jurnal Pendidikan Islam dan Manajemen Pendidikan Islam, 1(3), 418-440. https://doi.org/10.36671/andragogi.v1i3.66

Sanjaya, D. R. (2020). Atasi Psikosomatik dengan Terapi Puasa. GUEPEDIA.

Taubah, M. (2015). Pendidikan Anak dalam Keluarga Perspektif Islam. Jurnal Pendidikan Agama Islam (Journal of Islamic Education Studies), 3(1), 109136. https://doi.org/10.15642/jpai.2015.3.1.109-136

Umar, S. (2019). Pendidikan Masyarakat Berbasis Masjid. CV Budi Utama. 
Wulur, M. B. (2015). Psikoterapi Islam. Deepublish.

Yatim, F. L. (2002). Autisme: Suatu Gangguan Jiwa pada Anak-anak. Yayasan Obor Indonesia.

Zulkafli, N. S., Majid, L. A., \& Ishak, H. (2018). Inovasi Perubatan Melalui Terapi al-Quran Terhadap Kanak-Kanak Autisme. Al-Turath Journal of AlQuran and Al-Sunnah, 3(2), 40-45. 